\title{
Perfluorinated Quaternary \\ Ammonium Salts of \\ Polyoxometalate Anions: \\ Fluorous Biphasic Oxidation \\ Catalysis with and without \\ Fluorous Solvents
}

\author{
Galia Maayan, Richard H. Fish ${ }^{\dagger}$ and Ronny Neumann* \\ Department of Organic Chemistry, Weizmann Institute of Science, Rehovot, Israel \\ 76100
}

Ronny.Neumann@weizmann.ac.il

Received Date (will be automatically inserted after manuscript is accepted)

\section{ABSTRACT}

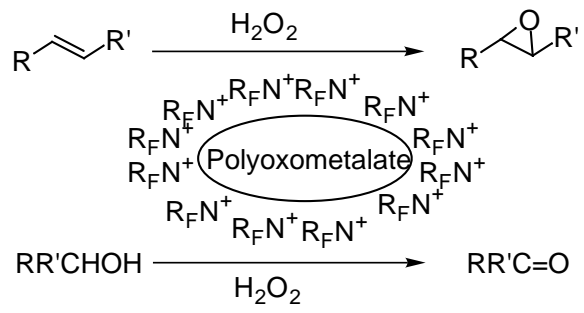

Perfluorinated quaternary ammonium cations, $\left[\mathrm{CF}_{3}\left(\mathrm{CF}_{2}\right)_{7}\left(\mathrm{CH}_{2}\right)_{3}\right]_{3} \mathrm{CH}_{3} \mathrm{~N}^{+}\left(\mathrm{R}_{\mathrm{F}} \mathrm{N}^{+}\right)$, were synthesized and used as counter cations for the $\left[\mathrm{WZnM}_{2}\left(\mathrm{H}_{2} \mathrm{O}\right)_{2}\left(\mathrm{ZnW}_{9} \mathrm{O}_{34}\right)_{2}\right]^{12-}(\mathrm{M}=\mathrm{Mn}(\mathrm{II}), \mathrm{Zn}(\mathrm{II}))$, polyoxometalate. The $\left(\mathrm{R}_{\mathrm{F}} \mathrm{N}^{+}\right)_{12}\left[\mathrm{WZnM}_{2}\left(\mathrm{H}_{2} \mathrm{O}\right)_{2}\left(\mathrm{ZnW}_{9} \mathrm{O}_{34}\right)_{2}\right]$ compounds were fluorous biphasic catalysts for alcohol and alkenol oxidation, and alkene epoxidation with aqueous hydrogen peroxide. Reaction protocols with or without a fluorous solvent were tested. The catalytic activity and selectivity was affected both by the hydrophobicity of the solvent and the substrate.

An important area of homogeneous catalysis research remains the quest for practical separation techniques of the intrinsically soluble catalyst from the remaining reaction components. One method that has quite recently attracted significant attention as a separation/recovery method is fluorous biphasic catalysis. ${ }^{1}$ The concept espouses

$\dagger$ Permanent address: Lawrence Berkeley National Laboratory, 70108B, University of California, Berkeley, CA 94720 USA.

(a) Horváth, I. T., Acc. Chem. Res. 1998, 31, 641-650. (b) Cavazzini, M.; Montanari, F.; Pozzi, G.; Quici, S. J. Fluorine Chem. modification of known catalytic entities with fluorous "ponytails" yielding catalysts soluble in very hydrophobic perfluorohydrocarbon solvents. Commonly, there are very temperature dependent organic substrate/fluorous solvent -

1999, 94, 183-193. (c) Bhattacharyya, P.; Croxtall, B.; Fawcett, J.; Fawcett, J.; Gudmunsen, D.; Hope, E. G.; Kemmitt, R. D. W.; Paige, D. R.; Russell, D. R.; Stuart, A. M.; Wood, D. R. W. J. Fluorine Chem. 2000, 101, 247-255. (d) Fish, R. H. Chem. Eur. J. 1999, 5, 1677-1680. (e) Barthel-Rosa, L. P.; Gladysz, J. A. Coord. Chem. Rev. 1999, 190-192, 587-605. (f) Vincent, J.-M.; Rabion, A.; Fish, R. H. ACS Symposium Ser. 2000, 767, 172-181. 
liquid/liquid phase miscibilities that allow single phase reactions at elevated reaction temperature and biphasic separation of the organic product from the fluorous solvent containing the catalyst at ambient or sub-ambient temperatures. In the context of catalytic oxidation, fluorous biphasic catalysis has been realized using various appropriately modified organometallic complexes. ${ }^{2}$ Questions concerning the environmental impact and degradability of perfluorinated solvents, along with their relative high cost have also led to the concept of fluorous phase catalysis without fluorous solvents. ${ }^{3}$ In such systems, perfluorinated thermomorphic catalysts are soluble in normal hydrocarbons at elevated temperatures but are immiscible in the solvent at decreased temperatures allowing the separation by precipitation of the fluorous catalyst from the product and solvent phase by cooling the reaction mixture.

Polyoxometalate anions have over recent years been investigated as oxidation catalysts using a variety of oxidants including the more sustainable molecular oxygen and hydrogen peroxide. ${ }^{4}$ Especially notable in the context of this paper is the use of "sandwich" type polyoxometalates, $\left[\mathrm{WZnM}_{2}\left(\mathrm{H}_{2} \mathrm{O}\right)_{2}\left(\mathrm{ZnW}_{9} \mathrm{O}_{34}\right)_{2}\right]^{12-}(\mathrm{M}=$ $\mathrm{Mn}(\mathrm{II}), \mathrm{Zn}(\mathrm{II})$ ), for catalytic oxidation of alkenes, alkenols and alcohols with aqueous hydrogen peroxide. ${ }^{5}$ Also in the area of polyoxometalate oxidation catalysis various techniques for separation/recovery of the polyoxometalate from the other reaction components have been considered.

2 (a) Vincent, J.-M.; Rabion, A.; Yachandra, V. K.; Fish, R. H. Angew. Chem. Int. Ed. Eng. 1997, 36, 2346-2349. (b) Vincent, J.-M.; Rabion, A.; Yachandra, V. K.; Fish, R. H. Can. J. Chem. 2001, 79, 888895. (c) Ragagnin, G.; Betzemeier, B.; Quici, S. Knochel, P. Tetrahedron 2002, 58, 3985-3991. (d) Klement, I.; Knochel, P. Synlett 1995, 11131114. (e) Klement, I.; Lutjens, H.; Knochel, P. Angew. Chem. Int. Ed. Eng. 1997, 36, 1454-1456. (f) Betzemeier, B.; Lhermitte, F.; Knochel, P. Tetrahedron Lett. 1998, 39, 6667-6670. (g) Betzemeier, B.; Knochel, P. Synlett 1999, 489-491. (h) Betzemeier, B.; Cavazzini, M.; Quici, S.; Knochel, P. Tetrahedron Lett.2000, 41, 4343-4346. (i) Pozzi, G.; Cavzzini, M.; Quici, S.; Maillard, D.; Sinou, D. J. Mol. Catal. A Chem. 2002, 182-183, 455-461. (j) Cavazzini, M.; Manfredi, A.; Montanari, F.; Quici, S.; Pozzi, G. Eur. J. Org. Chem. 2001, 4639-4649. (k) Pozzi, G.; Banfi, S.; Manfredi, A.; Montanari, F.; Quici, S. Tetrahedron 1996, 52, 11879-11888. (1) Pozzi, G.; Montanari, F.; Quici, S. Chem. Commun. 1997, 69-70. (m) Pozzi, G.; Colombani, I.; Miglioli, M.; Montanari, F.; Quici, S. Tetrahedron 1997, 53, 6145-6162. (n) Pozzi, G.; Cavazzini, M.; Quici, S.; Fontana, S. Tetrahedron Lett. 1997, 38, 7605-7608. (o) Quici, S.; Cavazzini, M.; Ceragioli, S.; Montanari, F.; Pozzi, G. Tetrahedron Lett. 1999, 40, 3647-3650. (p) Cavazzini, M.; Manfredi, A.; Montanari, F.; Quici, S. Pozzi, G.; Chem. Commun. 2000, 2171-2172. (q) Collonna, S.; Gaggero, N.; Montanari, F.; Pozzi, G.; Quici, S. Eur. J. Org. Chem. 2001, 181-186. (r) ten Brink, G.-J.; Vis, J. M.; Arends, I. W. C. E.; Sheldon, R. A. Tetrahedron 2002, 58, 3977-3983.

(a) Wende, M.; Meier, R.; Gladysz J. A. J. Am. Chem. Soc. 2001, 123, 11490-11491. (b) Wende, M.; Gladysz, J. A. J. Am. Chem. Soc. 2003, 125, 5861-5872.

(a) Kozhevnikov, I. V. Catalysis by Polyoxometalates, Wiley, Chichester, England, 2002. (b) Hill, C. L.; Prosser-McCartha, C. M. Coord. Chem. Rev, 1995, 143, 407-455. (c) Mizuno, N.; Misono, M. Chem. Rev. 1998, 98, 199-218. (d) Neumann, R. Prog. Inorg. Chem. 1998, 47, 317-370.

(a) Neumann, R.; Gara, M. J. Am. Chem. Soc. 1994, 116, 55095510. (b) Neumann, R.; Gara, M. J. Am. Chem. Soc. 1995, 117, 50665074. (c) Neumann, R.; Juwiler, D. Tetrahedron, 1996, 47, 8781-8788. (d) Adam, W.; Alsters, P. L.; Neumann, R.; Saha-Möller, C. R.; SlobodaRozner, D.; Zhang, R. Synlett, 2002, 2011-2014. (e) Adam, W.; Alsters, P. L.; Neumann, R.; Saha-Möller, C. R.; Sloboda-Rozner, D.; Zhang, R. J. Org. Chem. 2003, 68, 1721-1728.
These methods include supported catalysts, ${ }^{6}$ aqueous biphasic media, ${ }^{7}$ solvent anchored catalysts, ${ }^{8}$ and others. ${ }^{9}$ In this paper we report on our adaptation of the concept of biphasic fluorous phase catalysis into the realm of oxidation catalysis by polyoxometalates. We have found that thermomorphic fluorous polyoxometalates may be prepared and used in fluorous biphasic catalysis despite the polyanionic nature of the polyoxometalates by use of perfluorinated quaternary ammonium cations, $\left[\mathrm{CF}_{3}\left(\mathrm{CF}_{2}\right)_{7}\left(\mathrm{CH}_{2}\right)_{3}\right]_{3} \mathrm{CH}_{3} \mathrm{~N}^{+}$or $\left(\mathrm{R}_{\mathrm{F}} \mathrm{N}^{+}\right)$, as counter-cations. Consequently, effective catalytic oxidation reactions of alkenes, alkenols and alcohols can be carried out using "sandwich" type polyoxometalates, $\left(\mathrm{R}_{\mathrm{F}} \mathrm{N}^{+}\right)_{12}\left[\mathrm{WZnM}_{2}\left(\mathrm{H}_{2} \mathrm{O}\right)_{2}\left(\mathrm{ZnW}_{9} \mathrm{O}_{34}\right)_{2}\right]$, figure 1, with aqueous hydrogen peroxide as oxidant with or without fluorous solvents.

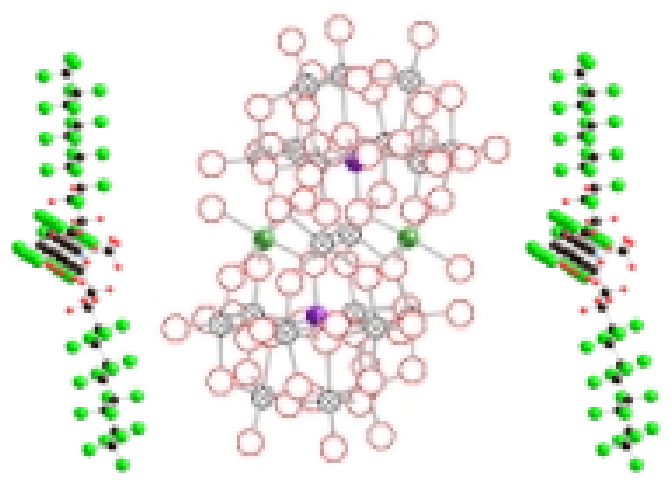

Figure 1. Representation of the $\left[\mathrm{WZnM}_{2}\left(\mathrm{H}_{2} \mathrm{O}\right)_{2}\left(\mathrm{ZnW}_{9} \mathrm{O}_{34}\right)_{2}\right]^{12-}$ polyoxometalate with two (out of twelve) $\left(\mathrm{R}_{\mathrm{F}} \mathrm{N}^{+}\right)$counter cations.

6 (a) Neumann, R.; Levin, M. J. Org. Chem. 1991, 56, 5707-5710. (b) Yamaguchi, K.; Mizuno, N. New J. Chem. 2002, 26, 972-974. (c) Okun, N. M.; Anderson, T. M.; Hill, C. L. J. Am. Chem. Soc. 2003, 125, 31943195. (d) Khenkin, A. M.; Neumann, R.; Sorokin, A. B.; Tuel, A. Catal. Letters 1999, 63, 189-192. (e) Neumann, R.; Miller, H. J. Chem. Soc., Chem. Commun. 1995, 2277-2778.

Sloboda-Rozner, D.; Alsters, P. L.; Neumann, R. J. Am. Chem. Soc. 2003, 125, 5280-5281.

(a) Neumann, R.; Cohen, M. Angew. Chem. Int. Ed. 1997, 36, 17381740. (b) Cohen, M.; Neumann, R. J. Mol. Catal. A 1999, 146, 293-300.

${ }^{9}$ Haimov, A.; Neumann, R. Chem. Commun. 2002, 876-877. 


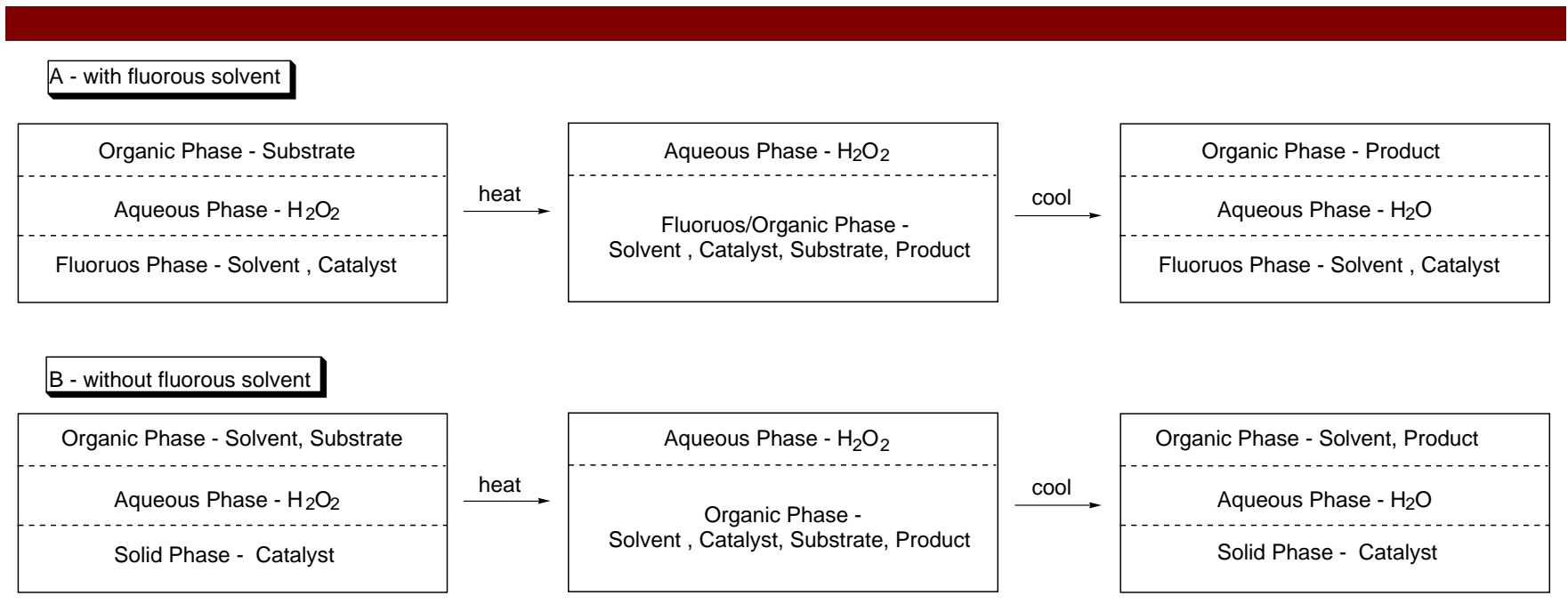

Figure 2: Reaction protocols for oxidation with aqueous hydrogen peroxide catalyzed by $\left(\mathrm{R}_{\mathrm{F}} \mathrm{N}^{+}\right)_{12}\left[\mathrm{WZnM}_{2}\left(\mathrm{H}_{2} \mathrm{O}\right)_{2}\left(\mathrm{ZnW}_{9} \mathrm{O}_{34}\right)_{2}\right]$.

The fluorous quaternary ammonium salt $\left\{\left[\mathrm{CF}_{3}\left(\mathrm{CF}_{2}\right)_{7}\left(\mathrm{CH}_{2}\right)_{3}\right]_{3} \mathrm{CH}_{3} \mathrm{~N}^{+}\right\} \mathrm{CH}_{3} \mathrm{OSO}_{3}^{-}$was prepared by quaternization of the known fluorous tertiary aliphatic amine, ${ }^{10}\left[\mathrm{CF}_{3}\left(\mathrm{CF}_{2}\right)_{7}\left(\mathrm{CH}_{2}\right)_{3}\right]_{3} \mathrm{~N}$, by dimethylsulfate. ${ }^{11}$ The fluorous polyoxometalates, ${ }^{12}$ $\left(\mathrm{R}_{\mathrm{F}} \mathrm{N}^{+}\right)_{12}\left[\mathrm{WZnM}_{2}\left(\mathrm{H}_{2} \mathrm{O}\right)_{2}\left(\mathrm{ZnW}_{9} \mathrm{O}_{34}\right)_{2}\right]$, were prepared by mixing twelve equivalents of $\left\{\left[\mathrm{CF}_{3}\left(\mathrm{CF}_{2}\right)_{7}\left(\mathrm{CH}_{2}\right)_{3}\right]_{3} \mathrm{CH}_{3} \mathrm{~N}^{+}\right\} \mathrm{CH}_{3} \mathrm{OSO}_{3}^{-}$with one equivalent of $\mathrm{Na}_{12}\left[\mathrm{WZnM}_{2}\left(\mathrm{H}_{2} \mathrm{O}\right)_{2}\left(\mathrm{ZnW}_{9} \mathrm{O}_{34}\right)_{2}\right]{ }^{13}$ The fluorine content by weight of $\left(\mathrm{R}_{\mathrm{F}} \mathrm{N}^{+}\right)_{12}\left[\mathrm{WZnM}_{2}\left(\mathrm{H}_{2} \mathrm{O}\right)_{2}\left(\mathrm{ZnW}_{9} \mathrm{O}_{34}\right)_{2}\right]$ is $51.5 \%$. Thus, despite the polyanionic character of the polyoxometalate, $\left(\mathrm{R}_{\mathrm{F}} \mathrm{N}^{+}\right)_{12}\left[\mathrm{WZnM}_{2}\left(\mathrm{H}_{2} \mathrm{O}\right)_{2}\left(\mathrm{ZnW}_{9} \mathrm{O}_{34}\right)_{2}\right]$ is freely soluble in perfluorohydrocarbons at room temperature. In other common solvents such as ethylacetate and toluene $\left(\mathrm{R}_{\mathrm{F}} \mathrm{N}^{+}\right)_{12}\left[\mathrm{WZnM}_{2}\left(\mathrm{H}_{2} \mathrm{O}\right)_{2}\left(\mathrm{ZnW}_{9} \mathrm{O}_{34}\right)_{2}\right]$ is insoluble at room temperature, but dissolves upon heating to $60-80$ ${ }^{\circ} \mathrm{C}$. This property leads to two different reaction protocols for the fluorous biphasic catalysis, figure 2: (a) with a

${ }^{10}$ Rocaboy, C.; Bauer, W.; Gladysz, J. A. Eur. J. Chem. 2000, 26212628.

${ }^{1}\left[\mathrm{CF}_{3}\left(\mathrm{CF}_{2}\right)_{7}\left(\mathrm{CH}_{2}\right)_{3}\right]_{3} \mathrm{~N}(400 \mathrm{mg}, 0.29 \mathrm{mmol})$ and $\mathrm{Me}_{2} \mathrm{SO}_{4}(0.04 \mathrm{~mL}$, $0.43 \mathrm{mmol}$ ) were dissolved in $6 \mathrm{~mL}$ of trifluorotoluene and refluxed overnight under Ar. Upon cooling the white waxy solid, $\left\{\left[\mathrm{CF}_{3}\left(\mathrm{CF}_{2}\right)_{7}\left(\mathrm{CH}_{2}\right)_{3}\right]_{3} \mathrm{CH}_{3} \mathrm{~N}^{+}\right\} \mathrm{CH}_{3} \mathrm{OSO}_{3}^{-}$, settled and was collected and dried. Yield $-0.405 \mathrm{~g}, 91 \%$. ${ }^{1} \mathrm{H}$ NMR $\left(\mathrm{CF}_{3} \mathrm{COOD}\right): \delta=3.87(\mathrm{~s}, 3 \mathrm{H}$, $\left.\mathrm{CH}_{3} \mathrm{O}\right), \delta=3.35-3.6\left(\mathrm{bm}, 6 \mathrm{H}, \mathrm{CH}_{2} \mathrm{~N}\right), \delta=3.19\left(\mathrm{~s}, 3 \mathrm{H}, \mathrm{CH}_{3} \mathrm{~N}\right), \delta=2.0$ $-2.4\left(\mathrm{bm}, 12 \mathrm{H}, \mathrm{CF}_{2} \mathrm{CH}_{2} \mathrm{CH}_{2}\right) \cdot{ }^{13} \mathrm{C} \mathrm{NMR}\left(\mathrm{CF}_{3} \mathrm{COOD} / \mathrm{CD}_{3} \mathrm{SOCD}_{3}\right): \delta=$ $63.97\left(\mathrm{~s}, \mathrm{CH}_{3} \mathrm{O}\right), \delta=59.03\left(\mathrm{~s}, \mathrm{CH}_{2} \mathrm{~N}\right), \delta=55.99\left(\mathrm{~s}, \mathrm{CH}_{3} \mathrm{~N}\right), \delta=30.09(\mathrm{t}$, $\left.\mathrm{CF}_{2} \mathrm{CH}_{2}\right), \delta=16.92\left(\mathrm{~s}, \mathrm{CF}_{2} \mathrm{CH}_{2} \mathrm{CH}_{2}\right)$. ES-MS (positive ion mode): $\mathrm{m} / \mathrm{z}=$ 1413. $\left(\left[\mathrm{CF}_{3}\left(\mathrm{CF}_{2}\right)_{7}\left(\mathrm{CH}_{2}\right)_{3}\right]_{3} \mathrm{CH}_{3} \mathrm{~N}+1\right)$, ES-MS (negative ion mode): $\mathrm{m} / \mathrm{z}$ $=111\left(\mathrm{CH}_{3} \mathrm{OSO}_{3}^{-}\right)$.

$\left.{ }_{12} \mathrm{Na}_{12}\left\{\left[\mathrm{WZnM}_{2}\left(\mathrm{H}_{2} \mathrm{O}\right)_{2}\right]\left(\mathrm{ZnW}_{9} \mathrm{O}_{34}\right)_{2}\right]\right\} \quad(\mathrm{M}=\mathrm{Mn}(\mathrm{II}), \mathrm{Zn}(\mathrm{II}))(62 \mathrm{mg}$, $11 \mu \mathrm{mol})$ dissolved in $2 \mathrm{~mL}$ water and $\left\{\left[\mathrm{CF}_{3}\left(\mathrm{CF}_{2}\right)_{7}\left(\mathrm{CH}_{2}\right)_{3}\right]_{3} \mathrm{CH}_{3} \mathrm{~N}^{+}\right\} \mathrm{CH}_{3} \mathrm{OSO}_{3}{ }^{-}(201 \mathrm{mg}, 132 \mu \mathrm{mol})$ dissolved in $8 \mathrm{~mL}$ trifluoroethanol were mixed and shaken for $5 \mathrm{~min}$. The product precipitated immediately and was collected and dried. Yield $-225 \mathrm{mg}$, 90\%. ${ }^{1} \mathrm{H}$ NMR (TFAOD): $\delta=3.35-3.55$ (bm, 6H), 3.19 (s, 3H), $2.05-$ $2.35(\mathrm{~m}, 12 \mathrm{H})$.

${ }^{13}$ Zonnevijlle, F.; Tourné, C. M.; Tourné, G. F. J. Chem. Soc. Dalton Trans. 1991, 143-155. perfluorohydrocarbon (perfluorodecalin) solvent and (b) without a fluorous solvent e.g. ethylacetate.

Results using the two catalytic reaction protocols for the oxidation of alcohols, alkenols and alkenes are presented in Tables $1-3$, respectively.

Table 1. Oxidation of aliphatic alcohols with $30 \%$ aqueous $\mathrm{H}_{2} \mathrm{O}_{2}$ catalyzed by $\left(\mathrm{R}_{\mathrm{F}} \mathrm{N}^{+}\right)_{12}\left[\mathrm{WZn}_{3}\left(\mathrm{H}_{2} \mathrm{O}\right)_{2}\left(\mathrm{ZnW}_{9} \mathrm{O}_{34}\right)_{2}\right]$.

Conversion, $\mathrm{mol} \%$

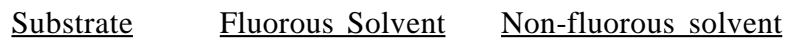

$\begin{array}{lcc}\text { 2-butanol } & 3 & 8 \\ \text { 2-pentanol } & 32 & 36 \\ \text { 2-hexanol } & 44 & 55 \\ \text { 2-heptanol } & 46 & 48 \\ \text { 2-octanol } & 67 & 28 \\ \text { cyclohexanol } & 43 & 82 \\ \text { 1-octanol } & 50^{\mathrm{a}} & 19^{\mathrm{b}}\end{array}$

Reaction conditions: $1 \mathrm{mmol}$ alcohol, $2 \mathrm{mmol} 30 \%$ aq. $\mathrm{H}_{2} \mathrm{O}_{2}, 1 \mathrm{~mL}$ perfluorodecalin or EtOAc, $5 \mu \mathrm{mol}\left(\mathrm{R}_{\mathrm{F}} \mathrm{N}^{+}\right)_{12}\left[\mathrm{WZn}_{3}\left(\mathrm{H}_{2} \mathrm{O}\right)_{2}\left(\mathrm{ZnW}_{9} \mathrm{O}_{34}\right)_{2}\right]$, $80^{\circ} \mathrm{C}, 8 \mathrm{~h}$. Analysis by GC - ketones were the only observed product . (a) $4 \%$ octanal, $76 \%$ octanoic acid, $20 \%$ octyloctanoate. (b) $15 \%$ octanal, $36 \%$ octanoic acid, $39 \%$ octyloctanoate

One may observe that secondary aliphatic alcohols were rather effectively oxidized to the expected ketones with without formation of by-products. For a representative primary alcohol, 1-octanol, one observes low selectivity, with formation first of octanal. Octanal may be further oxidized to octanoic acid or a reaction between octanal and 1-octanol leads to formation of a hemiacetal that is oxidized to the octyloctanoate ester. It is also interesting to note that there appear to be interesting trends of reactivity as a 
function of the length of the aliphatic chain. A fairly water soluble 2-butanol hardly reacts due to its limited solubility in EtOAc and perfluorodecalin in the presence of aqueous $\mathrm{H}_{2} \mathrm{O}_{2}$. For the shorter chain alcohols e.g. 2-pentanol, 2hexanol and also cyclohexanol, probably better solubility in EtOAc versus perfluorodecalin leads to higher conversion in the non-fluorous solvent. As the aliphatic chain is lengthened, the relative activity EtOAc/perfluorodecalin is inverted. 2-octanol is clearly more reactive in the fluorous phase.

Table 2. Oxidation of alkenols with $30 \%$ aqueous $\mathrm{H}_{2} \mathrm{O}_{2}$ catalyzed by $\left(\mathrm{R}_{\mathrm{F}} \mathrm{N}^{+}\right)_{12}\left[\mathrm{WZn}_{3}\left(\mathrm{H}_{2} \mathrm{O}\right)_{2}\left(\mathrm{ZnW}_{9} \mathrm{O}_{34}\right)_{2}\right]$.

\begin{tabular}{|c|c|c|}
\hline \multirow[b]{2}{*}{$\underline{\text { Substrate }}$} & \multicolumn{2}{|c|}{ Conversion (Selectivity) ${ }^{\mathrm{a}}, \mathrm{mol} \%$} \\
\hline & $\frac{\text { Fluorous }}{\underline{\text { Solvent }}}$ & $\frac{\text { Non-fluorous }}{\text { solvent }}$ \\
\hline$E$-2-hexen-1-ol & $95(94,6)$ & $53(72,28)$ \\
\hline Z-2-hexen-1-ol & $95(98,2)$ & $66(65,35)$ \\
\hline 3-Me-2-buten-1-ol & $43(100,0)$ & $100(100,0)$ \\
\hline Z-3-hexen-1-ol & $71(82,18)$ & $94(90,10)$ \\
\hline 5-hexen-1-ol & $58(97,3)$ & $56(96.4)$ \\
\hline 1-octen-3-ol & $66(0,100)$ & $35(0,100)$ \\
\hline cyclohexen-2-ol & $82(0,100)$ & $89(0,100)$ \\
\hline$(-)$-isopulegol ${ }^{\mathrm{b}}$ & $87(0,100)$ & $40(0,100)$ \\
\hline
\end{tabular}

Reaction conditions: $1 \mathrm{mmol}$ alcohol, $2 \mathrm{mmol} 30 \%$ aq. $\mathrm{H}_{2} \mathrm{O}_{2}, 1 \mathrm{~mL}$ perfluorodecalin or EtOAc, $5 \mu \mathrm{mol}\left(\mathrm{R}_{\mathrm{F}} \mathrm{N}^{+}\right)_{12}\left[\mathrm{WZn}_{3}\left(\mathrm{H}_{2} \mathrm{O}\right)_{2}\left(\mathrm{ZnW}_{9} \mathrm{O}_{34}\right)_{2}\right]$, $25^{\circ} \mathrm{C}$ (allylic alcohols) $60^{\circ} \mathrm{C}$ (other alkenols), $8 \mathrm{~h}$. Analysis by GC, GC-MS. (a) Selectivity is given as mol\% product/all products (\%epoxide,\% ketone or aldehdye). (b) (1R, 2S, 5R)-2-isopropenyl-5methylcyclohexanol.

Analysis of the results of the oxidation of alkenols needs to take into account at least five factors: (i) allylic versus non-allylic alcohols, (ii) secondary versus primary alcohols, (iii) secondary versus primary alkenes, (iv) fluorous versus non-fluorous solvents and (v) the hydrophilicity or hydrophobicity of the substrate. One general observation was that allylic alkenols were more reactive (reactions at ambient temperature) than non-allylic alkenols (reactions at $60{ }^{\circ} \mathrm{C}$ ). Furthermore, a general selectivity trend was observed - for alkenols with primary alcohol moieties, epoxidation is the predominant reaction whereas for alkenols with secondary alcohol moieties, alcohol oxidation is the predominant reaction. Selectivity to epoxidation was highest in 3-methyl-2-buten-1-ol due to the higher nucleophilicity of the alkene.

For the acyclic allylic primary alcohols tested, E-2hexen-1-ol, Z-2-hexen-1-ol, and 3-methyl-2-buten-1-ol, the mentioned chemoselectivity for epoxidation versus alcohol oxidation was retained. However, activity and selectivity was strongly dependent on the carbon chain length (hydrophobicity) and the nature of the solvent. 3-methyl-2buten-1-ol was more reactive in EtOAc compared to perfluorodecalin because it is relatively more hydrophilic. On the other hand, for 2-hexen-1-ol the opposite was observed, presumably because of improved solubility in perfluorodecalin. Importantly, the alcohol moiety was less reactive for 2-hexen-1-ol in perfluorodecalin than in EtOAc leading to improved chemoselectivity probably because of the limited miscibility of the $\mathrm{OH}$ group in the fluorous phase. Comparison of the reactivity of remaining substrates also clearly reveals that the more hydrophobic substrates were more reactive in perfluorodecalin compared to EtOAc and vice versa.

Table 3. Oxidation of alkenes with $30 \%$ aqueous $\mathrm{H}_{2} \mathrm{O}_{2}$ catalyzed by $\left(\mathrm{R}_{\mathrm{F}} \mathrm{N}^{+}\right)_{12}\left[\mathrm{WZnMn}_{2}\left(\mathrm{H}_{2} \mathrm{O}\right)_{2}\left(\mathrm{ZnW}_{9} \mathrm{O}_{34}\right)_{2}\right]$.

\begin{tabular}{lc}
\hline \multicolumn{1}{c}{ Substrate } & Conversion, mol\% \\
1-octene & 0 \\
E-2-octene & 3 \\
2-methyl-1-heptene & 5 \\
cyclododecene & 12 \\
cyclooctene & 52 \\
2-methyl-2-heptene & 64 \\
cyclohexene & 100 \\
1-methylcyclohexene & 100 \\
\hline
\end{tabular}

Reaction conditions: $1 \mathrm{mmol}$ alkene, $2 \mathrm{mmol} 30 \%$ aq. $\mathrm{H}_{2} \mathrm{O}_{2}, 1 \mathrm{~mL}$ toluene, $20 \mu \mathrm{mol}\left(\mathrm{R}_{\mathrm{F}} \mathrm{N}^{+}\right)_{12}\left[\mathrm{WZnMn}_{2}\left(\mathrm{H}_{2} \mathrm{O}\right)_{2}\left(\mathrm{ZnW}_{9} \mathrm{O}_{34}\right)_{2}\right], 60^{\circ} \mathrm{C}, 13 \mathrm{~h}$. Analysis by GC, GC-MS.

The reactivity of weakly nucleophilic alkenes was (very) low using the fluorous polyoxometalate catalyst, however, the more reactive cyclohexene and 1-methylcyclohexene reacted very nicely with this catalyst with no evidence of acid catalyzed epoxide ring opening and diol formation, which is unusual for such acid sensitive epoxides in the presence of hydrogen peroxide and absence of a buffer.

Perfluorinated quaternary ammonium salts of polyoxometalate anions can be used in fluorous biphasic oxidation catalysis with and without fluorous solvents for oxidation of alkenes, alkenols and alcohols with hydrogen peroxide. The solvent (fluorous or "normal") has an effect on reactivity and selectivity.

Acknowledgments. This research was supported by the Israel Science Foundation, the European Commission (G1RD-CT-2000-00347) and the Helen and Martin Kimmel Center for Molecular Design. R.H.F. thanks the Weston Foundation for funding a Visiting Professorship. R.N. is the Rebecca and Israel Sieff Professor of Organic Chemistry. 